\title{
SISTEM PENGENDALIAN INTERN TERHADAP FUNGSI PENERIMAAN KAS PADA PT. BANK MUAMALAT INDONESIA CABANG PEMATANGSIANTAR
}

\author{
M. Fauzan \\ STIKOM Tunas Bangsa Pematangsiantar, Sumatera Utara-Indonesia \\ Jalan Jendral Sudirman Blok A No. 1, 2, 3 Pematangsiantar \\ Email : mfauzan57@yahoo.com atau m.fauzan@stikomtb.ac.id
}

\begin{abstract}
Abstrak
Penelitian ini dilakukan untuk melihat sistem pengendalian intern terhadap fungsi penerimaan kas pada PT. Bank Muamalat Indonesia cabang Pematangsiantar. Data penelitian ini menggunakan data berupa slip setoran dan laporan harian transaksi penerimaan kas serta dokumen yang berkaitan dengan fungsi penerimaan kas di perusahaan. Data primer yang dikumpulkan dalam penelitian ini diperoleh melalui teknik angket atau kuesioner yang berisikan pernyataan-pernyataan yang diajukan secara tertulis kepada responden untuk mendapatkan jawaban serta informasi yang diperlukan dalam penelitian ini. Selain itu, data primer juga dapat diperoleh melalui teknik wawancara kepada informan penelitian dan observasi, Bank Muamalat Indonesia cabang Pematangsiantar ini beralamatkan di di Komplek Megaland Blok A Jl. Sangnawaluh No. 6-7, Pematangsiantar Sumatera Utara. Dari hasil pengolahan data yang ada diperoleh hasil bahwa sistem pengendalian intern terhadap fungsi penerimaan kas di PT. Bank Muamalat Indonesia cabang Pematangsiantar sudah dilaksanakan dengan baik. Hal ini dapat dilihat dari hasil observasi yang diperoleh yaitu 3,20 yang terdapat pada interval 2,51 - 3,25 dengan kategori "Baik".
\end{abstract}

Kata-Kata Kunci: Sistem Pengendalian Intern, Fungsi Penerimaan, Penerimaan Kas Teller 


\section{A. Pendahuluan}

Sejak 1970, lembaga keuangan Islam telah berkembang dengan pesat dan menyebar secara luas diseluruh dunia. Di Indonesia, perkembangan lembaga keuangan Islam mulai dirintis sejak tahun 1980an. Namun upaya yang lebih intensif dilakukan oleh para aktivis muda Islam pada tahun 1990-an. Yang mencapai puncaknya pada musyawarah Nasional IV Majelis Ulama Indonesia di Jakarta pada tanggal 22-25 Agustus 1990 yang menghasilkan amanat bagi pembentukan kelompok kerja tim perbankan MUI. Hasil kerja tim ini adalah pendirian PT. Bank Muamalat Indonesia pada 1 November 1991. Sebagai bank yang mengusung mekanisme perbankan syariah yang pertama di Indonesia. Dalam kurun waktu dua dasawarsa ini ekonomi Islam berkembang dengan pesat, ditandai dengan banyaknya pendirian bank-bank syariah (baik yang menerapkan sistem murni syariah maupun dual window) serta maraknya lembaga keuangan syariah non bank seperti Baitul Mal Wa Tamwil, BPR Syariah, Asuransi Syariah, Pegadaian Syariah, Reksadana Syariah, Pasar Modal Syariah serta Lembaga Zakat, Infak, Sedekah dan Wakaf.

Praktik perbankan syariah di Indonesia secara perlahan menunjukkan perkembangan yang signifikan. Hal ini ditandai dengan adanya Undang-Undang No. 10 Tahun 1998 tentang perbankan dimana membolehkan bank-bank konvensional untuk membuka Unit Usaha Syariah (UUS) atau cabang syariah yang biasanya disebut dengan dual banking system dan kini Undang-Undang No. 21 Tahun 2008 tentang perbankan syariah, dimana perbankan syariah adalah segala sesuatu yang menyangkut tentang bank syariah dan unit usaha syariah, mencakup kelembagaan, kegiatan usaha serta cara dan proses dalam melaksanakan kegiatan usahanya.

Dalam perkembangannya di Indonesia, praktek perbankan syariah bermula tahun 1992 dengan beroperasinya PT. Bank Muamalat Indonesia, Tbk. PT. Bank Muamalat Indonesia, Tbk merupakan bank pertama murni syariah yang lahir sebagai hasil kerja tim perbankan MUI 
dan para ikatan Cendikiawan Muslim Indonesia (ICMI) tersebut berdiri pada tanggal 1 November 1991 dengan modal disetor Rp.106.126.382.000,00 telah dapat beroperasi pada tanggal 1 Mei 1992. Berbekal dengan sistem bagi hasil dan penghapusan bunga pada operasional bank konvensional pada umumnya yang dinyatakan riba dalam syariat dan ajaran Islam, Bank Muamalat mampu mengatasi badai krisis dua kali dalam sejarah yaitu krisis 1997-1998 serta krisis global pada tahun 2008.

Kas merupakan salah satu harta perusahaan yang sangat penting karena dalam menjalankan usahanya setiap perusahaan selalu membutuhkan uang kas, kas diperlukan baik untuk membiayai kegiatan perusahaan sehari-hari. Kas dalam neraca merupakan aktiva yang paling likuid karena hampir setiap transaksi yang dilakukan oleh fungsi yang berwenang atau yang terkait di dalam perusahaan maupun dengan pihak luar yang sebagian besar akan mempengaruhi kas. Selain itu kas bersifat mudah dipindahtangankan sehingga kas merupakan aktiva yang sangat diperhatikan karena mudah digelapkan dan dimanipulasi.

Setiap perusahaan pada umumnya mengadakan pengawasan yang ketat terhadap kas, untuk menghindari terjadinya penggelapan kas atau penyimpangan yang mencolok terhadap kas. Keadaan ini akan mendorong perusahaan untuk melakukan penataan pada sistem akuntansi penerimaan kas yang meliputi beberapa aspek yang saling berkaitan diantaranya sistem pengendalian intern yang terbagi dari dua unsur yaitu pengendalian administrasi dan pengendalian akuntansi.

Sistem pengendalian intern merupakan semua cara untuk melindungi harta kekayaan perusahaan dan ditaatinya akan kepatuhan hukum dan peraturan yang di berlakukan di perusahaan. PT. Bank Muamalat Indonesia cabang Pematangsiantar adalah salah satu lembaga perbankan yang memadukan idealisme usaha dengan nilai-nilai rohani yang melandasi kegiatan operasionalnya yang melakukan kegiatan penghimpunan dana, penyaluran atau pembiayaan dana dan pelayanan jasa. 
Di dalam menjalankan kegiatan operasionalnya sebagai perusahaan jasa PT. Bank Muamalat Indonesia cabang Pematangsiantar tentunya menggunakan kedua unsur sistem pengendalian intern sebagai alat kendali untuk melindungi harta kekayaannya dan ditaatinya pelaksanaan kepatuhan terhadap aturan yang berlaku.

Salah satu unsur sistem pengendalian intern yaitu pengendalian akuntansi yang berhubungan langsung dengan penyimpanan harta kekayaan dan pencatatan atas transaksi-transaksi yang terjadi terutama dalam penerimaan kas pada PT. Bank Muamalat Indonesia cabang Pematangsiantar.

Pada PT. Bank Muamalat Indonesia cabang Pematangsiantar pihakpihak yang terlibat dalam fungsi penerimaan kas diantaranya yaitu nasabah, teller dan operation officer di dalam kegiatan penerimaan kas pada PT. Bank Muamalat Indonesia cabang Pematangsiantar. Teller salah satu petugas dalam penerimaan kas merangkap fungsi penerimaan kas atau dengan kata lain adanya petugas yang menjalankan lebih dari satu fungsi penerimaan kas, maka diperlukan sistem pengendalian terhadap fungsi penerimaan kas secara tepat.

Kebutuhan akan sistem pengendalian intern sebagai alat untuk mengendalikan kegiatan penerimaan kas merupakan suatu yang wajar karena dengan adanya praktik pengendalian yang baik memrefleksikan adanya manajerial yang baik.

Berdasarkan uraian tersebut di atas, maka penulis tertarik untuk mengangkat hal tersebut dalam sebuah penelitian dengan judul "Sistem Pengendalian Intern Terhadap Fungsi Penerimaan Kas Pada PT. Bank Muamalat Indonesia cabang Pematangsiantar".

\section{B. Kajian Teori}

Sebelumnya istilah yang dipakai untuk pengendalian intern adalah sistem pengendalian intern, sistem pengawasan intern dan struktur pengendalian intern. Mulai tahun 2001 istilah resmi yang digunakan IAI adalah pengendalian intern. Ikatan Akuntansi Indonesia mendefinisikan pengendalian intern sebagai suatu proses yang dijalankan oleh dewan 
komisaris, manajemen dan personel lain entitas yang didesain untuk memberikan keyakinan memadai tentang pencapaian tiga golongan tujuan berikut ini yaitu:

a. Keandalan pelaporan keuangan.

b. Efektivitas dan efisiensi operasi.

c. Kepatuhan terhadap hukum dan peraturan yang berlaku (Agoes Soekirno, 2004).

Sistem Pengendalian intern dapat mempunyai beberapa pengertian yaitu sistem pengendalian intern dalam arti sempit dan dalam arti luas. Dalam arti sempit, istilah tersebut sama dengan pengertian internal check yang merupakan prosedur-prosedur mekanis untuk memeriksa ketelitian data-data administrasi misalnya mencocokkan penjumlahan mendatar (horizontal) dengan penjumlahan melurus (vertical). Dalam arti luas sistem pengendalian intern dapat dipandang sebagai sistem sosial (social system) yang mempunyai wawasan atau makna khusus yang berada dalam organisasi perusahaan. Sistem tersebut terdiri dari kebijakan, teknik, prosedur, alat-alat fisik, dokumentasi, orang-orang yang berinteraksi satu sama lain yang diarahkan untuk (a) melindungi harta, (b) menjamin terhadap"terjadinya hutang yang tidak layak", (c) menjamin ketelitian dan dapat dipercayainya data akuntansi, (d) dapat diperolehnya operasi yang efisien dan (e) menjamin di taatinya kebijakan perusahaan (Akmal, 2009).

Tujuan sistem pengendalian intern adalah:

1. Menjaga kekayaan organisasi

Harta fisik perusahaan dapat dicuri, disalahgunakan. Sistem pengendalian intern dibentuk guna mencegah ataupun menemukan harta yang hilang.

2. Mengecek ketelitian dan keandalan data akuntansi

Manajemen harus memiliki data akuntansi yang dapat diuji ketepatannya untuk melaksanakan operasi perusahaan berbagai macam data yang digunakan untuk mengambil keputusan yang penting. 
3. Mendorong efisiensi usaha

Pengendalian dalam suatu perusahaan juga dimaksud untuk menghindari pekerjaan-pekerjaan berganda yang tidak perlu, mencegah pemborosan terhadap semua aspek usaha termasuk pencegahan terhadap penggunaan sumber-sumber dana yang efisien.

4. Mendorong dipatuhinya kebijakan manajemen

Manajemen menyusun prosedur dan peraturan untuk mencapai tujuan perusahaan. Sistem pengendalian initern memberikan jaminan akan ditaatinya prosedur dan peraturan tersebut oleh perusahaan.

Keempat tujuan tersebut dapat digolongkan menjadi dua macam yaitu, pengendalian intern akuntansi (internal accounting control) dan pengendalian intern administratif (internal administrative control). Pengendalian intern akuntansi meliputi rencana organisasi dan semua cara dan prosedur terutama yang menyangkut dan berhubungan langsung dengan pengamanan harta milik dan dapat dipercayainya administrasi keuangan yang ada. Secara tegas pengendalian akuntansi meliputi sistem pemberian wewenang (authorization) dan sistem persetujuan (approval) perusahaan antara tugas-tugas penyimpanan harta kekayaan dan tugastugas pencatatan, pengawasan fisik atas kekayaan yang bersangkutan. Sedangkan pengendalian intern administrasi meliputi rencana organisasi dan semua cara dan prosedur yang terutama menyangkut efisiensi usaha dan ketaatan terhadap kebijaksanaan pimpinan perusahaan dan pada umumnya tidak langsung berhubungan dengan catatan-catatan keuangan yang termasuk pengawasan disini misalnya tentang prosedur kerja analisa statistik, latihan pegawai, rencana cuti, mutasi pegawai dan seterusnya (Mulyadi, 2002).

Pengendalian intern terhadap fungsi penerimaan kas merupakan pengendalian intern yang saling memisahkan fungsi antara pencatatan dan pengurusan kas yang jelas dan bertujuan untuk menghindari terjadinya kecurangan-kecurangan atau penyelewengan-penyelewengan yang kemungkinan terjadi dalam perusahaan. Dengan adanya 
pengendalian intern ini maka penerimaan kas dalam perusahaan tidak dapat digelapkan oleh siapapun.

Sistem pengendalian intern terhadap fungsi penerimaan kas harus:

1. Memisahkan penyimpanan dan akuntansi untuk kas.

2. Mencatat semua transaksi kas.

3. Memelihara hanya saldo kas minimum yang dibutuhkan.

4. Melaksanakan perhitungan priodik atas saldo kas.

5. Melakukan rekonsiliasi atas saldo akun kas buku besar dan saldo kas bank.

6. Memperoleh pengembalian yang layak atas saldo kas yang menganggur.

7. Melakukan Pengendalian fisik atas kas.

Prosedur minimal yang perlu diterapkan dalam pengendalian intern penerimaan kas adalah:

1. Pemisahan tanggung jawab untuk menangani kas, mencatat transaksi kas dan merekonsiliasi saldo kas, pemisahan ini mengurangi kemungkinan pencurian dan penggelapan melalui pencatatan palsu.

2. Memberikan tanggung jawab penanganan dan pencatatan kas kepada orang yang berlainan untuk memastikan arus kas masuk dapat disetorkan tanpa terhambat. Pengendalian ini membutuhkan perhitungan, pencatatan dan penabungan yang segera dari kas yang diterima.

3. Melakukan pengawasan yang ketat atas semua fungsi penanganan dan pencatatan kas. Pengendalian ini membutuhkan perhitungan kas secara rutin dan mendadak, audit internal, serta pelaporan harian atas penerimaan, pembayaran dan saldo kas (Mulyadi, 2001).

Beberapa ciri pengendalian intern yang baik atas kas dan setara kas serta transaksi penerimaan dan pengeluaran kas adalah :

a. Adanya pemisahan tugas dan tanggung jawab antara yang menerima dan mengeluarkan kas dengan yang melakukan pencatatan, memberikan otoritas atas pengeluaran dan penerimaan kas. 
b. Pegawai yang membuat rekonsiliasi bank dibuat harus lain dari pegawai yang mengerjakan buku bank. Rekonsiliasi bank dibuat setiap bulan dan harus di telaah atau direview oleh kepala bagian akuntansi.

c. Digunakannya imprest fund system untuk mengelola kas kecil.

d. Penerimaan kas, cek dan giro harus disetor ke bank dalam jumlah seutuhnya intact paling lambat keesokan harinya.

e. Uang kas harus dikelola dengan baik, dalam arti jangan dibiarkan menganggur atau terlalu banyak disimpan di rekening giro karena tidak memberikan hasil yang optimal. Jika ada uang kas yang mengganggur sebaiknya disimpan dalam deposito berjangka atau dibelikan surat berharga yang sewaktu-waktu bisa diuangkan marketable sehingga bisa menghasilkan bunga atau dividen.

f. Uang kas harus disimpan di tempat yang aman seperti di cash box, brankas atau di bank.

g. Sebaiknya cek dan giro harus disimpan ditempat yang aman supaya tidak disalahgunakan. Selain itu harus dihindari penandatanganan cek dalam bentuk blanko. Pada saat penandatanganan cek harus dilampirkan buikti-bukti pendukung yang lengkap.

h. Sebaiknya cek dan giro ditulis atas nama dan cek atau giro ditandatangani 2 orang untuk menghindari penyalahgunaan.

i. Sebaiknya teller diasuransikan atau diminta menyerahkan uang jaminan untuk back up seandainya terjadi kehilangan uang atau kecurangan yang dilakukan oleh teller.

j. Digunakan kwintansi yang bernomor urut tercetak (prenumbered).

k. Bukti-bukti pendukung dari pengeluaran kas yang sudah dibayar harus distempel lunas untuk menghindari kemungkinan untuk diproses pembayarannya dua kali (double payment) (Dyckman, 2000).

Di dalam perusahaan perbankan fungsi penerimaan dilakukan oleh beberapa karyawan diantaranya adalah:

1. Teller merupakan fungsi penerimaan yang langsung berhubungan dengan nasabah, seorang teller harus memiliki sifat yang ramah, sopan terhadap para nasabah, selain itu teller merupakan karyawan bank yang 
bertanggung jawab terhadap lalu lintas uang tunai. Teller disebut juga kuasa kas terbatas karena dalam jumlah uang terbatas karyawan bank tersebut dapat bertindak secara langsung untuk melakukan transaksi.

2. Head teller merupakan atasan teller yang fungsinya membantu kegiatan teller dalam hal pengisian cash box teller pada pagi hari dan melakukan otorisasi terhadap penarikan yang diatas limit seorang teller.

3. Operational officer merupakan fungsi penerimaan kas yang bertanggung jawab atas seluruh kegiatan operasional perusahaan dalam hal penerimaan kas operasional officer menjalankan fungsinya menyimpan uang tunai dan berkas-berkas serta surat-surat berharga ke dalam ruang khasanah. Di dalam ruangan tersebut terdapat dua lemari besi yang kuat konstruksinya untuk penyimpanan uang tunai dan penyimpanan surat-surat dan berkas yang berharga. Selain itu operasional officer juga membuat laporan keuangan perusahaan.

Dalam pencatatan transaksi kas dikenal 2 (dua) macam buku harian yaitu:

a. Buku harian penerimaan kas atau cash receipt journal.

b. Buku harian pengeluaran kas atau cash payment journal.

Prosedur penerimaan kas dalam perusahan perlu dirancang sedemikian rupa sehingga tidak tercatat dan tidak diterimanya uang yang seharusnya diterima dapat dikurangi menjadi sekecil mungkin. Prosedur penerimaan kas perlu memperhatikan hal-hal sebagai berikut:

1. Terdapat pemisahan tugas antara yang menyimpan, yang menerima dan yang mencatat penerimaan uang. Apabila untuk sebuah perusahaan kecil pemisahan demikian tidak dapat dilakukan maka penggabungan antara kerja tugas tadi hanya dapat dilakukan oleh pemilik perusahaan.

2. Setiap penerimaan uang langsung disetor ke bank sebagaimana adanya.

\section{Metode Penelitian}

Pengumpulan data dilakukan penulis dengan menggunakan lembar observasi tertutup sebagai alat untuk mengumpulkan data yang berkaitan dengan masalah yang diteliti. 


\section{a. Jenis Data}

Data dalam penelitian ini penulis menggunakan data sekunder yang relevan yaitu data yang di peroleh dari perusahaan dalam bentuk sudah jadi, seperti sejarah singkat dan struktur organisasi perusahaan, laporan harian transaksi penerimaan kas dan lain sebagainya.

b. Sumber data

Sumber data yang digunakan dalam penelitian ini adalah berupa slip setoran dan laporan harian transaksi penerimaan kas serta dokumen yang berkaitan dengan fungsi penerimaan kas di perusahaan.

Data primer yang dikumpulkan dalam penelitian ini diperoleh melalui teknik angket atau kuesioner yang berisikan pernyataanpernyataan yang diajukan secara tertulis kepada responden untuk mendapatkan jawaban serta informasi yang diperlukan dalam penelitian ini. Selain itu, data primer juga dapat diperoleh melalui teknik wawancara kepada informan penelitian dan observasi.

Untuk memperoleh informasi dan data yang di butuhkan dalam penelitian ini, maka penulis menggunakan tehnik pengumpulan data melalui:

a. Teknik observasi tertutup (Pengamatan Langsung) yaitu suatu teknik pengumpulan data dengan mengamati secara langsung objek penelitian dan dengan memberi tanda check list pada lembar observasi.

Variabel penelitian ini diukur dengan menggunakan lembar observasi yang berisi pernyataan yang diukur dengan skala likert dengan bobot nilai 1- 4 dimana dari nilai-nilai tersebut dapat ditarik kesimpulan: (Sugiyono, 2002)

$\begin{array}{lll}\text { Jawaban } & \text { Skor } \\ \text { Sangat baik } & =4 \\ \text { Baik } & =3 \\ \text { Kurang baik } & =2 \\ \text { Tidak Baik }= & 1\end{array}$


Sebelum lembar observasi disusun perlu dibuat kisi-kisi lembar observasi,maka sistem pengendalian intern terhadap fungsi penerimaan kas dapat dilihat dalam tabel di bawah ini: (Teguh Pudjo Muljono, 1991)

Tabel 1. Kisi-kisi alat pengumpul data sistem pengendalian intern terhadap fungsi penerimaan kas

\begin{tabular}{|c|c|c|c|}
\hline No & Komponen & Nomor Butir & Total \\
\hline 1 & $\begin{array}{l}\text { Sistem } \\
\text { pengendalian } \\
\text { intern }\end{array}$ & $1,2,3,4,5,6,7,8$ & 8 \\
\hline 2 & $\begin{array}{l}\text { Fungsi } \\
\text { penerimaan } \\
\text { kas }\end{array}$ & $9,10,11,12,13,14,15$ & 7 \\
\hline & & Total & 15 \\
\hline
\end{tabular}

b. Teknik studi dokumen yaitu melakukan pencatatan dan pengopian atas data sekunder, akan tetapi dikarenakan data perusahaan bersifat sangat rahasia maka penulis hanya dapat mengamati laporan harian kas dan melakukan pengopian hanya slip setoran saja.

Sistem pengendalian intern merupakan cara yang dilakukan struktur organisasi perusahaan untuk melindungi harta kekayaan perusahaan, sistem pengendalian intern sebagai alat kendali dalam menjalankan aktivitas operasional perusahaan. Fungsi penerimaan kas merupakan keseluruhan sistem kerja yang dilakukan suatu bagian yang memiliki jabatan dan wewenang yang terlibat dalam kegiatan transaksi penerimaan kas. Sistem pengendalian intern terhadap fungsi penerimaan kas merupakan alat kendali terhadap keseluruhan sistem kerja fungsi yang berkaitan dengan kegiatan transaksi kas.

Metode analisis data yang digunakan dalam penelitian ini adalah teknik statistik deskriptif. Statistik deskriptif adalah statistik yang digunakan untuk menganalisa data dengan cara mendeskripsikan atau menggambarkan data yang telah terkumpul sebagaimana adanya tanpa 
bermaksud membuat kesimpulan yang berlaku umum atau generalisasi. Untuk melihat sejauh mana kecendrungan variabel tersebut maka digunakan rumus sebagai berikut: (Rasdian Rasyad, 2001)

Range (rentang) $=$ Data terbesar - Data terkecil

Panjang Kelas $=$ Rentang

$$
\begin{aligned}
& \text { Jumlah kode interval } \\
= & \frac{4-1}{4}
\end{aligned}
$$

$$
=0,75
$$

Sedangkan untuk mengukur validitas hasil observasi digunakan rata-rata (mean) dengan rumus sebagai berikut:

$\mathbf{X}=\sum \mathbf{X i}$

$$
\mathbf{N}
$$

Keterangan:

$\mathbf{X}=$ Nilai rata-rata hasil observasi

$\Sigma \mathbf{X i}=$ Total skor hasil observasi (merupakan penjumlahan $\mathrm{X} 1+\mathrm{X} 2+\ldots+\mathrm{Xn})$

$\mathbf{n} \quad=$ Jumlah unsur observasi

Setelah hasil observasi diperoleh, maka dapat diketahui sistem pengendalian intern terhadap fungsi penerimaan kas pada PT. Bank Muamalat Indonesia cabang Pematangsiantar dengan kriteria sebagai berikut:

$1,00-1,75=$ Sistem pengendalian intern terhadap fungsi penerimaan kas belum dilaksanakan dengan baik.

$1,76-2,50=$ Sistem pengendalian intern terhadap fungsi penerimaan kas kurang dilaksanakan dengan baik.

2,51-3,25 = Sistem pengendalian intern terhadap fungsi penerimaan kas sudah dilaksanakan dengan baik.

3,26-4,00 = Sistem pengendalian intern terhadap fungsi penerimaan kas sudah dilaksanakan dengan sangat baik. 


\section{Hasil dan Pembahasan}

\section{Sejarah Perusahaan}

Sejarah pendirian Bank Muamalat berawal dari lokakarya Bunga Bank dan Perbankan yang diselenggarakan Majelis Ulama Indonesia pada tanggal 18-20 Agustus 1990 di Cisarua, Bogor. Ide ini berlanjut dalam Musyawarah Nasional IV Majelis Ulama Indonesia di Hotel Sahid Jaya, Jakarta, pada tanggal 22-25 Agustus 1990 yang diteruskan dengan pembentukan kelompok kerja untuk mendirikan bank murni syariah pertama di Indonesia.

Realisasinya dilakukan pada tanggal 1 November 1991 yang ditandai dengan penandatangan akte pendirian PT Bank Muamalat Indonesia di Hotel Sahid Jaya berdasarkan Akte Notaris Nomor 1 tanggal 1 November 1991 yang dibuat oleh notaris Yudo Paripurno, SH dengan Izin Menteri Kehakiman Nomor C2.2413.T.01.01 tanggal 21 Maret 1992/Berita Negara Republik Indonesia tanggal 28 April 1992 Nomor 34.

Pada saat penandatanganan akte pendirian ini diperoleh komitmen dari berbagai pihak untuk membeli saham sebanyak Rp. 84 miliar. Kemudian dalam acara silaturahmi pendirian di Istana Bogor diperoleh tambahan dana dari masyarakat Jawa Barat senilai Rp. 106 miliar sebagai wujud dukungan mereka.

Dengan modal awal tersebut dan berdasarkan Surat Keputusan Menteri Keuangan RI Nomor 1223/MK.013/1991 tanggal 5 November 1991 serta izin usaha yang berupa Keputusan Menteri Keuangan Republik Indonesia Nomor 430/KMK.013/1992 tanggal 24 April 1992. Bank Muamalat Indonesia mulai beroperasi pada tanggal 1 Mei 1992 bertepatan 27 Syawal 1412 H. Pada tanggal 27 Oktober 1994, Bank Muamalat Indonesia mendapat kepercayaan dari Bank Indonesia sebagai Bank Devisa.

\section{Produk-Produk Bank Muamalat Indonesia}

Dalam menjalankan kegiatan usahanya sehari-hari PT. Bank Muamalat Indonesia cabang Pematangsiantar dapat dibagi dalam beberapa jenis kegiatan yang meliputi: 


\section{a. Produk Penghimpunan Dana (Funding)}

Produk-produk pengimpunan dana (funding) yang terdapat di PT. Bank Muamalat Indonesia cabang Pematangsiantar, yaitu Tabungan Muamalat Prima, Tabungan Muamalat Rencana, Tabungan Muamalat Umroh, Tabungan Haji Arafah, Tabungan Haji Arafah Dollar, Tabungan Muamalat Dollar, Tabungan Muamalat Sahabat, Tabunganku, Giro Muamalat Ultima, Giro Muamalat Attijary, Deposito Mudharabah, Deposito Fulinves, Pensiun terproteksi Muamalat dan Pensiun Untuk Kompensasi Pesangon.

b. Produk Penyaluran Dana (Lending)

Produk-produk penyaluran dana (lending) yang terdapat di PT. Bank Muamalat Indonesia cabang Pematangsiantar, yaitu Murabahah (Jual Beli), Jual Beli Salam, Jual Beli Istishna', Mudharabah (Bagi Hasil), Musyarakah (Kongsi), ljarah (Sewa Menyewa) dan ljarah Muntahiya Bittamlik.

c. Produk Jasa

Produk-produk jasa yang terdapat di PT. Bank Muamalat Indonesia cabang Pematangsiantar, yaitu Wakalah (Perwakilan), Kafalah (Penjaminan), Hawalah (Pengalihan Hutang), Qardh (Pinjaman Kebajikan), Sharf (Valuta Asing) dan layanan e-Muamalat yang terdiri dari Salam Muamalat, Internet Banking Muamalat, Mobile Banking Muamalat, Virtual Account Muamalat, Cash Management System Muamalat dan Gerai Muamalat (PPOB).

\section{Daerah Pemasaran}

Daerah pemasaran produk-produk Bank Muamalat Indonesia cabang Pematangsiantar meliputi Pematangsiantar dan Simalungun sekitarnya khususnya dan Sumatera Utara umumnya.

\section{Sistem Pengendalian Intern pada PT. Bank Muamalat Indonesia Cabang Pematangsiantar}

Seperti yang telah diuraikan pada bab sebelumnya bahwa sistem pengendalian intern merupakan suatu proses untuk mencapai tujuan tertentu. Sistem pengendalian intern juga merupakan alat kendali dalam 
melakukan aktivitas operasional perusahaan. Sistem pengendalian intern pada PT. Bank Muamalat Indonesia cabang Pematangsiantar meliputi dua unsur, yaitu pengendalian akuntansi dan pengendalian administrasi. Pengendalian akuntansi meliputi pemisahan fungsi, sistem pemberian wewenang dan sistem persetujuan PT. Bank Muamalat Indonesia cabang Pematangsiantar antara tugas-tugas penyimpanan aktiva, tugas-tugas pencatatan, pengawasan fisik atas aktiva dan adanya pemeriksaan intern secara bebas. Sedangkan pengendalian administrasi meliputi rencana organisasi dan semua cara yang terutama menyangkut efisiensi usaha dan ketaatan terhadap kebijaksanaan kepala cabang Pematangsiantar.

\section{Sistem Pengendalian Intern Terhadap Fungsi Penerimaan Kas Pada PT. Bank Muamalat Indonesia Cabang Pematangsiantar}

Seperti yang telah diuraikan pada bab sebelumnya bahwa kas adalah sebagai objek yang diperdagangkan dalam perusahaan perbankan maka hampir seluruh bagian dalam hal organisasi perusahaan bank terlibat dalam pengelolaan dan pengendalian kas. Namun dalam pengendalian intern terhadap fungsi penerimaan kas, bagian teller merupakan fungsi penerimaan kas yang memegang peranan yang amat penting karena bagian inilah yang menjadi terminal dan pintu gerbang dalam penerimaan uang kas. Disamping itu, pengendalian terhadap kas dibagian teller ini dapat ditambahkan sebagai berikut:

a. Setiap teller mempunyai limit sesuai yang ditentukan oleh perusahaan di dalam cash boxnya yaitu 25 juta setiap hari.

b. Semua transaksi uang tunai dengan nasabah hanya dilakukan oleh teller, ditangani dalam ruang teller yang terdapat cctv. Setiap teller juga akan dilengkapi dengan peralatan-peralatan untuk menyimpan uang tunai atau barang-barang berharga lain pada posisi counternya.

c. Teller hanya menyimpan uang secukupnya, sesuai dengan kebutuhan pembayaran sehari-hari. Namun demikian harus dihindarkan juga jangan sampai teller memegang uang tunai yang terlampau sedikit, sehingga sering terjadi perpindahan uang tunai antara teller dan operational officer selama jam kerja. 
d. Ruangan teller dilengkapi dengan pintu dan kunci yang harus tetap terkunci apabila di dalam berisi uang tunai. Hanya orang yang telah diberi wewenang sesuai dengan tugasnya, yang diperbolehkan memasuki ruangan teller.

e. Teller tidak boleh meninggalkan tempatnya jika terdapat uang tunai. Apabila terpaksa sebelum meninggalkan ruang teller, teller harus mengamankan semua uang tunai dan barang-barang berharga yang berada di bawah pengawasannya di dalam ruangan yang terkunci. Selama jam buka kas, ruangan teller tidak boleh ditinggalkan kosong.

f. Setiap teller di lengkapi dengan mesin pembuat tanggal atau hari (validating machine) dengan kode yang menunjukkan nama cabang bank dan nomor teller. Teller akan memberikan perlindungan yang sama terhadap kode bank ini seperti perlindungan yang diberikan terhadap uang tunai. Semua cek, giro bilyet, draft, tanda bukti setoran dan lainnya yang ditangani oleh teller wajib dicap dengan mesin validating atau dengan stempel teller bila tidak digunakan mesin validating.

g. Setiap teller memiliki kotak uang (cash box) yang diberi nomor dan kunci. Kotak-kotak tersebut harus tetap terkunci dan wajib diawasi oleh operation officer yang merangkap sebagai head teller selama waktu pemindahan dari dan ke ruang khasanah.

h. Teller juga dilengkapi dengan mesin yang dapat mendeteksi tanda tangan seluruh nasabah dan ia bertanggung jawab terhadap pemeriksaan tanda tangan nasabah.

i. Setiap bundel uang yang akan disetorkan ke dalam kas besar wajib dihitung secara terperinci terlebih dahulu kemudian wajib diikat dengan pengikat kertas yang berlogo Bank Muamalat Indonesia yang tersedia.

j. Semua uang tunai, baik di dalam khasanah yaitu lemari besi (kluis) dan kotak uang teller (cash box) maupun yang ada di dalam perjalanan diasuransikan dari kebakaran, perampokan dan pencurian.

Beberapa jenis peralatan yang digunakan pada bagian teller, yang berfungsi untuk mendukung pengendalian terhadap kas. Peralatanperalatan tersebut meliputi: 


\section{a. Vault compartment}

Merupakan ruangan khusus tempat menyimpan barang-barang berharga seperti surat-surat jaminan nasabah yang melakukan pembiayaan, surat-surat berharga, dan lain-lain. Oleh karena ruangan ini berisi dengan benda-benda berharga dan bersifat khusus, maka segala sesuatu mengenai penggunaan ruangan ini dibuat dan diatur secara ketat.

b. Cash compartment

Dapat berupa brankas atau lemari besi yang digunakan untuk menyimpan uang tunai.

c. Vault record

Berupa semacam cacatan yang memuat mutasi barang-barang yang ada dalam vault compertment yang diketahui oleh pegawai bagian kas.

d. Cash vault register

Cetakan yang memuat mutasi uang tunai dari ruangan vault compertment, di dalam catatan ini dimasukkan secara terperinci jumlah mata uang, jenis-jenis pecahan mata uang maupun jenis-jenis mata uang yang bermutasi setiap hari.

e. Counter

Sebuah ruangan tempat teller menjalankan tugas untuk melayani transaksi tunai para nasabah dan karena fungsi ini maka ruangan counter dibuat sedemikian rupa sehingga dapat untuk melayani nasabah secara cepat, tepat, ramah dan aman. Di dalam ruangan counter ini sesuai dengan fungsi dan kondisinya dilengkapi dengan beberapa perangkat perlengkapan teller, antara lain:

a) Peti uang atau cash box

Cash box ini harus dilengkapi dengan sistem 2 kunci,satu kunci dipegang oleh teller dan kunci lainnya di pegang supervisor.

b) Lampu ultra violet

Untuk mengecek keabsahan alat bayar atau media perintah lainnya.

c) Kaca pembesar minimal 8 kali pembesaran. 
d) $Q$ - Arert (untuk Bank Note atau valuta asing).

e) Alarm atau alat signal pengamanan.

f) Specimen tanda tangan atau alat untuk memeriksa atau verifikasi kebenaran tanda tangan nasabah.

g) Mesin hitung uang, yang terdiri dari mesin hitung untuk uang kertas dan uang logam.

h) Perangkat komputer atau alat memproses transaksi.

i) Printer atau alat untuk cetak transaksi.

j) Tell stroke atau kalkulator.

k) Stempel-stempel dan bantalan stempelnya.

I) Password dan sandi sebagai sarana akses ke dalam sistem.

Karena ruangan ini merupakan ruangan khusus yang tidak semua orang diizinkan untuk memasukinya, maka teller sebagai orang bertanggung jawab terhadap ruangan ini, tidak diperkenankan mengizinkan mereka tidak berhak untuk memasuki ruangan ini, kecuali:

a) Operational officer.

b) Internal auditor.

c) Pemeriksaan dari Bank Indonesia untuk tujuan pemeriksaan bank.

\section{Hasil Observasi}

Tabel 2. Hasil Observasi

\begin{tabular}{|c|c|c|c|c|c|}
\hline \multirow{3}{*}{$\mathrm{N}$} & \multirow{3}{*}{ Unsur Observasi } & \multicolumn{4}{|c|}{ Hasil Observasi } \\
\hline & & SB & B & KB & TB \\
\hline & & 4 & 3 & 2 & 1 \\
\hline 1 & $\begin{array}{l}\text { Adanya terdapat pembagian } \\
\text { fungsionil yang tegas antara teller, } \\
\text { headteller, operation manager dan } \\
\text { administrasi. }\end{array}$ & & 3 & & \\
\hline 2 & $\begin{array}{l}\text { Kartu-kartu spesimen tanda tangan } \\
\text { nasabah telah: } \\
\text { a. Diadministrasi dengan baik. } \\
\text { b. Dilegalisir oleh pejabat yang berwenang } \\
\text { untuk itu. } \\
\text { c. Dikuasai oleh pejabat yang berwenang } \\
\text { untuk itu. }\end{array}$ & & 3 & & \\
\hline 3 & $\begin{array}{l}\text { Adanya terdapat pembagian tugas untuk } \\
\text { menyimpan kunci-kunci khasanah atau } \\
\text { strongroom. }\end{array}$ & & 3 & & \\
\hline 4 & $\begin{array}{l}\text { Adanya jumlah pegawai jumlahnya } \\
\text { mencukupi. }\end{array}$ & & 3 & & \\
\hline 5 & $\begin{array}{l}\text { Kualitas pegawai sesuai dengan tanggung } \\
\text { jawabnya. }\end{array}$ & & 3 & & \\
\hline
\end{tabular}




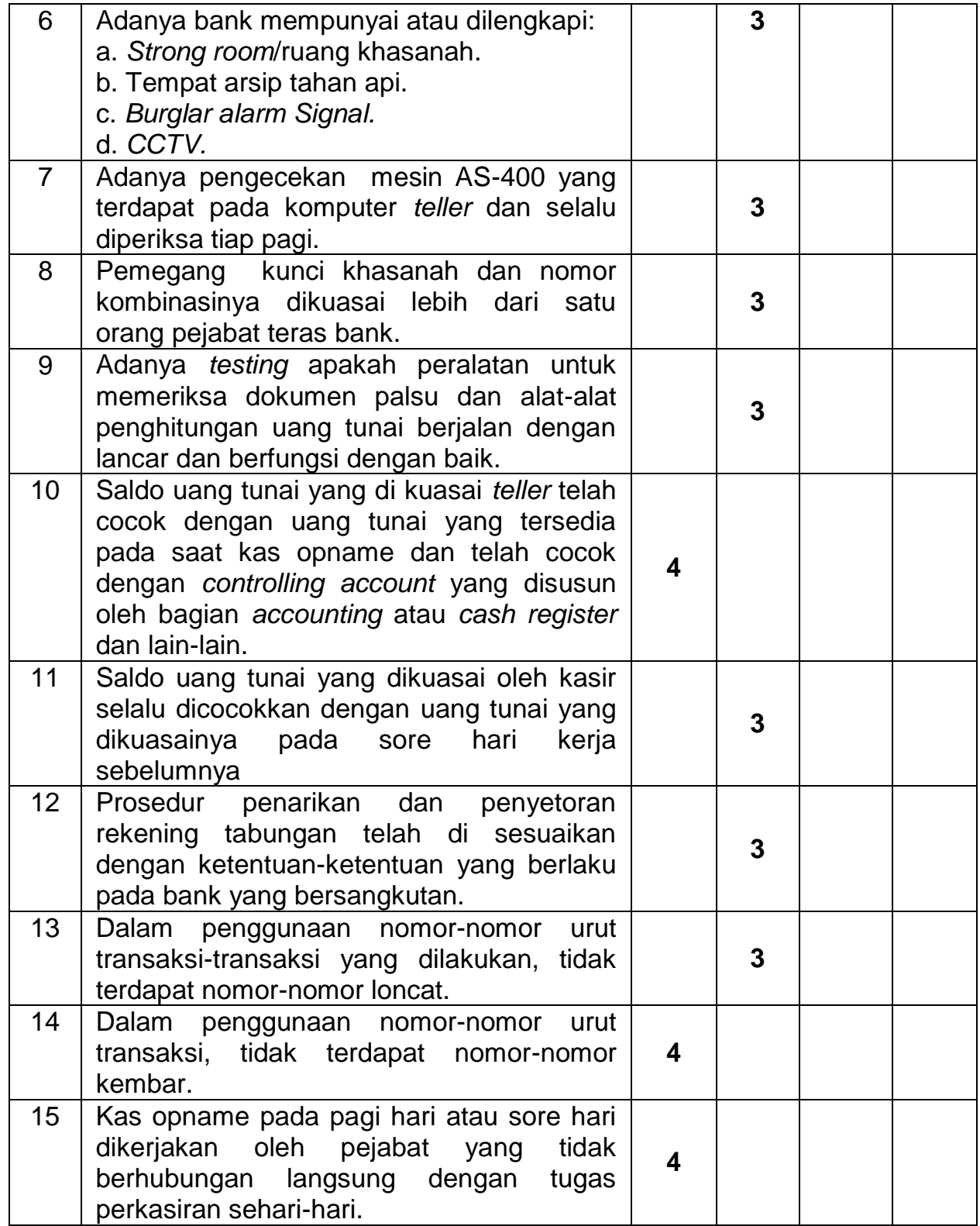

Dari tabel hasil observasi tersebut, maka diperoleh nilai rata-rata dengan menggunakan rumus:

a. Mean (rata-rata)

$X=\sum X i=\underline{3+3+3+3+3+3+3+3+3+4+3+3+3+4+4}$

$\mathrm{N}$

15

$=\underline{48}=3,20$

15

Dari hasil observasi yang diperoleh, maka dapat dilihat dari kriteria sebagai berikut: 


\section{Tabel 3. Penilaian Sistem Pengendalian Intern Terhadap Fungsi Penerimaan Kas}

\begin{tabular}{|c|c|}
\hline Interval & Kategori \\
\hline $3,26-4,00$ & Sangat Baik \\
\hline $2,51-3,25$ & Baik \\
\hline $1,76-2,50$ & Kurang Baik \\
\hline $1,00-1,75$ & Tidak Baik \\
\hline
\end{tabular}

Dari hasil penelitian yang penulis lakukan pada PT. Bank Muamalat Indonesia cabang Pematangsiantar, dalam melaksanakan sistem pengendalian intern terhadap fungsi penerimaan kas diperoleh hasil 3,20 yang terdapat pada interval 2,51 - 3,25 dengan kategori "Baik". Dalam arti, bahwa sistem pengendalian intern terhadap fungsi penerimaan kas sudah berjalan dengan baik.

Selain itu penelitian yang dilakukan penulis di PT. Bank Muamalat Indonesia cabang Pematangsiantar dalam pelaksanaanya perusahaan telah menggunakan prosedur penerimaan kas seperti yang telah diuraikan pada bab sebelumnya, yaitu teller menerima slip setoran dan sejumlah uang tunai dari nasabah (penyetor). Kemudian teller memeriksa atau menghitung jumlah uang dihadapan nasabah dan membandingkan dengan jumlah dalam angka dan huruf pada slip setoran. Selanjutnya teller mencocokkan nomor rekening dan nama pemegang rekening, jika terdapat perbedaan antara jumlah yang disetor dengan jumlah uang seperti tercantum dalam slip setoran maka teller memberitahukan kepada nasabah dengan segera. Teller juga memberitahu kepada nasabah dengan segera, jika terdapat bagian kolom yang belum di tuliskan oleh nasabah pada slip setoran. Kemudian teller memeriksa tanda tangan penyetor yang ada pada slip setoran dan akan melakukan posting transaksi tersebut ke dalam sistem dimenu "setoran tunai" dengan menginput nomor referensi, nomor rekening, nilai transaksi, keterangan, sebagai daftar transaksi penerimaan kas. Selanjutnya slip setoran yang telah divalidasi oleh teller disimpan sebagai bukti fisik penerimaan kas, 
dan salinan slip setoran dikembalikan kepada nasabah sebagai bukti penerimaan.

\section{Kesimpulan dan Saran}

\section{Kesimpulan}

Berdasarkan hasil pembahasan diatas, penelitian ini dapat disimpulkan yaitu sistem pengendalian intern terhadap fungsi penerimaan kas di PT. Bank Muamalat Indonesia cabang Pematangsiantar sudah dilaksanakan dengan baik. Hal ini dapat dilihat dari hasil observasi yang diperoleh yaitu 3,20 yang terdapat pada interval 2,51 - 3,25 dengan kategori "Baik".

\section{Saran}

1. Kepada pihak PT. Bank Muamalat Indonesia cabang Pematangsiantar disarankan melakukan penambahan kuantitas karyawan yang memiliki kualitas yang baik dengan melakukan seleksi yang ketat, untuk mendapatkan karyawan yang cakap dalam melakukan aktivitas perusahaan terutama fungsi penerimaan kas.

2. Kepada pihak PT. Bank Muamalat Indonesia cabang Pematangsiantar disarankan mengadakan evaluasi dan pelatihan kerja secara periodik terhadap fungsi yang menangani kas, kegiatan tersebut bermanfaat sebagai alat untuk mengadakan correction action atau perbaikan tindakan yang dilakukan fungsi penerimaan kas. 


\section{DAFTAR RUJUKAN}

Agoes Sukirno. 2004. Auditing (Pemeriksaan Akuntan Oleh Kantor Akuntan) Jilid I Edisi Ketiga. Lembaga Penerbit Fakultas Ekonomi Universitas Indonesia. Jakarta.

Akmal. 2009. Pemeriksaan Manajemen Internal Audit. PT. Indeks. Jakarta.

Baridwan, Zaki. 1987. Sistem akuntansi: Bagian Penerbitan Akademi Akuntansi. YKPN. Yogyakarta.

Dyckman. 2000. Akuntansi Intermediate, Edisi Ketiga. Erlangga. Jakarta.

Em Zul Fajri dan Ratu Aprilia Senja. 2008. Kamus Lengkap Bahasa Indonesia. Difa Publisher. Jakarta.

Ikatan Akuntansi Indonesia. 2004. Standar Akuntansi Keuangan. Salemba Empat. Jakarta.

Mulyadi. 2002. Auditing Edisi ke Enam. Salemba Empat. Jakarta.

Mulyadi. 2001. Sistem Akuntansi. Salemba Empat. Jakarta.

Mulyadi. 1990. Pemeriksaan Akuntansi Edisi 3. Bagian Penerbitan STIE YKPN. Yogyakarta.

Sugiono. 2002. Metodologi penelitian Bisnis. CV. Alfabet. Bandung.

Teguh Pudjo Muljono. 1991. Bank Auditing Petunjuk Pemeriksaan Intern Bank. Penerbit Djambatan. Jakarta.

Zaki Badirwan. 1987. Sistem Akuntansi. Bagian Penerbitan Akademi Akuntansi YKPN. Yogyakarta. 